DOI: http://doi.org/10.21698/simi.2018.fp31

\title{
NEW ECOLOGICAL SOLUTION TO COMBAT THE VEGETATION IN EXCESS IN NATURAL AND HYDROPOWER LAKES
}

\author{
Victorita Radulescu
}

University Politehnica of Bucharest, Faculty of Energy, Department of Hydraulics, Hydraulic machinery and Environmental engineering, 313 Splaiul Independentei, district 6, Bucharest, vradul4@gmail.com, Romania

\begin{abstract}
In Romania on Bistrita and Siret Rivers were realized between 1960-1970, 15 hydropower plants, some of them being today Natural Reservations. Due to improper management of the water quantity, the capacity of the lakes was reduced, mostly due to excessive, invasive development of vegetation. A specific problem appears in the Vaduri Lake, which is Natural Reservation. Part of the water is used for human necessities for more than 200 localities, and part for electric energy. The lake represents an ecologic environmental for more than 30 species of birds which nest here and for another 78 species who are passing during migration. For them is necessary a clean surface of the lake and a good quality of the water. It was realized a prototype using renewable resources, as to collect and partially dry the collected vegetation for future utilization in a biomass power plant. This new solution activated by solar panels is efficient, optimal, and ecologic, being tested in the lake in the last two years. First are briefly analyzed the local conditions responsible for the ecological changes, affecting the entire environment. First are mentioned the previously tested solutions, without any effect. Some bird species decreased as a number, and some of them disappeared, due to the improper conditions for nesting. This new solution is realized on a mobile pontoon, which moves constantly with a small velocity, without perturbing the ecosystem. It has the possibility of displacement into the affected area, without noise, which could perturb the bird life. Finally, some conclusions and references are presented.
\end{abstract}

Keywords: environmental engineering, natural reservation, prototype, renewable resources, water conservation

\section{Introduction}

In the Romanian Energetic System, on Bistrita and Siret Rivers the hydropower lakes are realized around 50 years ago. New and permanent problems appear, needed constantly to be solved (Shumway 1990). One of them is represented by the massive decrease of the lake's volume capacity, partially due to sedimentation, and partially due to the eutrophication. In present, more than 8 such hydropower lakes have the capacity reduced by more than $60 \%$ since their commissioning. The hydropower development of the River Bistrita is formed by 11 hydropower plants 


\section{INTERNATIONAL SYMPOSIUM "THE ENVIRONMENT AND THE INDUSTRY", SIMI 2018, PROCEEDINGS BOOK}

and was accomplished during 1960-1970. The Lake Vaduri, finished in 1964, was declared in 2004 Natural Reservation, has a surface of 1500 ha, offering favorable conditions, necessary food and shelter for many species of wintering and migratory birds as summer swan, high duck, rattle duck, Little Grebe, northern pintail, duck with redhead, Common Pochard. Here is the largest population of the wintering whooper swan from Romania besides the Danube Delta.

Nowadays the lake confronts with a massive development of the aquatic vegetation, due to the eutrophication (Rodhe 1979) produced mainly by the new woodworking factories and paper manufacturing. Consequently, the nitrites and the nitrates added into water have led to an explosion of the aquatic vegetation growth (Smith 1999).

In the past were tried different solutions. Part of them is not recommended in Natural Reservations or for lakes with water supply for population, as it is the Lake Vaduri. The presented solution is totally ecologic, using renewable resources, well adapted to the wild bird's life.

\section{Materials and Methods}

Under natural conditions, the phosphor is the main nutrient, which provides the synthesis of new tissue, being categorized before the nitrogen and carbon, (Seteanu \& Radulescu 1997, Martin 1994) in vegetation development. Therefore, the phosphor represents a "limiting factor" influencing the increase or decrease of the algal proliferations (Cole 1993, Lawton 1991). The human activities, domestic, industrial, or agricultural, induce a nitrogen deficiency that stimulates the proliferation of cyanobacteria capable of binding the molecular nitrogen. Table 1 presents the measured parameters during the campaigns of 2010-2015.

Table 1. Values of the hydro-chemical supply

\begin{tabular}{|c|c|c|c|c|}
\hline Element & Symbol & $\begin{array}{c}\text { Vegetal consumption } \\
\%\end{array}$ & $\begin{array}{c}\text { Water Supply } \\
\%\end{array}$ & $\begin{array}{l}\text { Consumption / Supply } \\
\text { (approx). }\end{array}$ \\
\hline Oxygen & $\mathrm{O}$ & 80.5 & 89 & 1 \\
\hline Hydrogen & $\mathrm{H}$ & 9.7 & 11 & 1 \\
\hline Carbon & $\mathrm{C}$ & 6.5 & 0.0012 & 5,000 \\
\hline Silicon & $\mathrm{Si}$ & 1.3 & 0.00065 & 2,000 \\
\hline Azoth & $\mathrm{N}$ & 0.7 & 0.000023 & 30,000 \\
\hline Calcium & $\mathrm{Ca}$ & 0.4 & 0.0015 & $<1,000$ \\
\hline Potassium & $\mathrm{K}$ & 0.3 & 0.00023 & 1,300 \\
\hline Phosphor & $\mathrm{P}$ & 0.08 & 0.000001 & 80,000 \\
\hline Magnesium & $\mathrm{Mg}$ & 0.07 & 0.0004 & $<1,000$ \\
\hline Sulfur & S & 0.06 & 0.0004 & $<1,000$ \\
\hline Chlorine & $\mathrm{Cl}$ & 0.06 & 0.0008 & $<1,000$ \\
\hline Sodium & $\mathrm{Na}$ & 0.04 & 0.0006 & $<1,000$ \\
\hline Iron & $\mathrm{Fe}$ & 0.02 & 0.00007 & $<1,000$ \\
\hline Boron & B & 0.001 & 0.00001 & $<1,000$ \\
\hline Manganese & Mn & 0.0007 & 0.0000015 & $<1,000$ \\
\hline Zinc & $\mathrm{Zn}$ & 0.0003 & 0.000001 & $<1,000$ \\
\hline Cupper & $\mathrm{Cu}$ & 0.0001 & 0.000001 & $<1,000$ \\
\hline Molybdenum & Mo & 0.00005 & 0.0000003 & $<1,000$ \\
\hline Cobalt & Co & 0.000002 & 0.000000005 & $<1,000$ \\
\hline
\end{tabular}




\section{INTERNATIONAL SYMPOSIUM "THE ENVIRONMENT AND THE INDUSTRY", SIMI 2018, PROCEEDINGS BOOK}

As a result of the vegetative cell's multiplication may occur eutrophication at the lake's surface, who can be colored in red or blue-green, depending on the predominant species of cyano-bacteria (Duce 2008). These colonial algae reach the surface carried by the lake's currents or by the bubbles of gases.

For a proper analysis of the parameters responsible for the excess development of vegetation were made measurements for the sediments and water characteristics for three lakes, including Lake Vaduri. The results of quantitative determination from this area are presented in Table 2.

Table 2. Average values of physical-chemical parameters of sediments

\begin{tabular}{|c|c|c|c|c|}
\hline $\mathrm{Nr}$ & Parameter & $\begin{array}{c}\text { Lake } \\
\text { Pangarati }\end{array}$ & $\begin{array}{c}\text { Lake } \\
\text { Vaduri }\end{array}$ & $\begin{array}{c}\text { Lake } \\
\text { Reconstuctia }\end{array}$ \\
\hline 1 & Humidity $\left(105^{0} \mathrm{C}\right) \%$ & 55.46 & 53.38 & 55.66 \\
\hline 2 & $\mathrm{pH}$ (upH) & 6.80 & 6.65 & 7.04 \\
\hline 3 & Organic substance (\%) & 6.95 & 5.93 & 8.36 \\
\hline 4 & Mineral Substance (\%) & 93.05 & 94.07 & 91.64 \\
\hline 5 & $\mathrm{NH}_{4}^{+}(\mathrm{mg} / 100 \mathrm{~g})$ & 5.85 & 7.27 & 8.01 \\
\hline 6 & $\mathrm{NH}_{4}^{+}(\mathrm{mg} / \mathrm{l})$ & 105.48 & 136.19 & 143.91 \\
\hline 7 & $\mathrm{NO}_{3}^{-}(\mathrm{mg} / 100 \mathrm{~g})$ & 0.33 & 0.41 & 0.19 \\
\hline 8 & $\mathrm{NO}_{3}^{-}(\mathrm{mg} / \mathrm{l})$ & 5.95 & 7.68 & 3.41 \\
\hline 9 & $\mathrm{PO}_{4}^{3-}(\mathrm{mg} / 100 \mathrm{~g})$ & 0.068 & 0.072 & 0.086 \\
\hline 10 & $\mathrm{PO}_{4}^{3-}(\mathrm{mg} / \mathrm{l})$ & 1.22 & 1.34 & 1.54 \\
\hline 11 & $\mathrm{~N}-\mathrm{NH}_{4}^{+}+\mathrm{N}-\mathrm{NO}_{3}^{-}(\mathrm{mg} / 100 \mathrm{~g})$ & 4.61 & 5.74 & 6.27 \\
\hline 12 & $P-P O_{4}^{3-}(m g / 100 g)$ & 0.022 & 0.023 & 0.028 \\
\hline 13 & $\mathrm{~N}_{\text {dissolved }} / \mathrm{P}_{\text {dissolved }}$ & 209.54 & 249.56 & 223.93 \\
\hline
\end{tabular}

\section{Previously tested solutions}

The hydropower Lake Vaduri has multiple utilizations besides the electric energy production. It assures the water supply for the surrounding population and is a RAMSAR site, a Natural Reservation representing a biological ecosystem needed to be protected. Due to the water supply for the population is necessary to be maintained at a certain level of water's quality as to protect also the existing flora and fauna. The excessive growth of vegetation significantly reduced the volume of water that can be processed for energy purposes, but also affect the life quality for specific birds, of their nesting, etc. In the last decades have been tested several solutions, some of them improper and inadequate for this lake.

\section{Chemical products}

Here were used two possibilities based on different types of developed vegetation. 


\section{INTERNATIONAL SYMPOSIUM "THE ENVIRONMENT AND THE INDUSTRY", SIMI 2018, PROCEEDINGS BOOK}

\section{Algaecides}

The solution uses derivatives of the copper and is recommended on lake's surfaces covered by algae. The effect is rapid, destroying the vegetation. The mixture is spread on water surfaces and has best results when is applied on a calm sunny day. Generally, heavy infestations were treated, but only for small surfaces, in different stages. At intervals of 5-7 days, the treatment should be repeated. The re-treatment during the growing season (spring-summer) is absolutely required and is more efficient when a new growth of algae begin to appear. The solution may be applied only at small lakes, without water circulation. Because the lake Vaduri is also used for water supply, the solution was rapidly abandoned.

Herbicides

Represent a better solution to control the development of the aquatic vascular plants, easy to be applied, almost in the same manner as the algaecides. It is necessary to pour the solution into the lake's water, in different locations with a high density of vegetation. It is recommended to be used when the plants are actively growing, and the water temperature is above $15^{\circ} \mathrm{C}$. This solution does not destroy the algae roots and is efficient in lakes where the water does not flow. In hydropower lakes, there is a permanent current of water, produced by the turbine functioning during the electric energy production. This solution was tested but without efficiency in Lake Vaduri. In many European countries, this solution is completely forbidden, because affects the bird's life. This solution should not be applied, since the lake is a Natural Reservation, used also for water supply of the population.

\section{Biological additives}

Utilization of the biological solutions to inhibit the algae growth generally assures an improving of the water's quality, but in this lake, the vegetation has reached high values, difficult to be destroyed with this method. In these conditions would be necessary high quantities of biological additives, with high concentration. Anyway, the efficiency of this solution at large scale is reduced, due to the water movement. The solution was tested for three months. Taking account that the water is used for human supply, the Commissions of the Environmental Protection and of the Public Health have rejected it immediately.

Grass Carp

This solution was tested with good results in different lakes, but outside Romania. It is represented by populating the lakes with some carp species, which feed especially with aquatic vegetation. These species were imported from China. In Romania, the solution was not efficient. The local authorities tried two times to populate the lake with such fish, in different years. Nobody checked the natural conditions needed for the fish surviving. They are living only a temperature almost constant, around $15^{\circ} \mathrm{C}$ $24^{0} \mathrm{C}$. Into the Vaduri Lake, more than 7 months/year the temperature is around $10^{\circ} \mathrm{C}$ or lower and generally, freezes most of it in winter. In these conditions, the fish died. Anyway, the solution was not accepted by the ecologists, which were afraid do not disturb the natural eco-system. 


\section{INTERNATIONAL SYMPOSIUM "THE ENVIRONMENT AND THE INDUSTRY", SIMI 2018, PROCEEDINGS BOOK}

\section{Mechanical control}

There are two solutions of cutting and removing the vegetation mainly with the same purpose, but with different efficiency and applicability.

Harvesters - remove the plants from the water, until depths of about $1 \mathrm{~m}$, with a conveyor system. It is solved the problems associated with the decay of the cut plants, being disposed of onshore. Some harvesters are large enough to haul up to 13 tons of vegetation. Densely packed, the vegetation can weigh 200 tons for a lake with a surface of around $100 \mathrm{~m}^{2}$. Unfortunately, this solution also kills the fish, amphibians, reptiles, birds, bird nests, and other wildlife by including them in the harvested plant material.

Rotovator - uses the rototiller blades, for cutting at $0.5-0.8 \mathrm{~m}$ from the lake's bottom, extracting the almost entire plant or the branched plants. It may be used for plants with buoyant roots and crowns. The solution is adequate for large surfaces of water, preferable to be used during winter or spring when most of the plants have died. They disturb the sediments on the bottom, increase the water turbidity, releases the nutrients from the sediments, but also the toxic residues bounded in the sediments. They also disturb in the lake's bottom the sinking animals, the fish's spawn, and their migration. There are many EU countries where they are not used.

As a conclusion, the methods tested until now were not efficient solutions. The chemical and biological methods to combat the vegetation in Natural Reservation, due to the risk of destroying the local ecosystem, are impossible to be applied. The parasitic species have a rapid growth in detriment of endemic fish species from the protected area. The only accepted solution and tested, was with cutting vegetation machines, but the reality proved that was not efficient in time. In the subsequent years, the areas where the vegetation was trimmed, the remained roots of aquatic species have developed stronger, more branched, more vigorous plants.

\section{Results and Discussion}

The proposed solution is a prototype (Romanian patent pending) placed on a mobile pontoon, commanded from distance, and powered in co-generation by the photovoltaic panels (PV). The Photovoltaic panels ensure the pontoon movement and partially the energetic supply of the collecting, partial drying, and compacting of the vegetation systems. The main advantage of this solution is that the extracted vegetation can be consumed, immediately, and integrally, into a biomass power plant. The moving model is based on three main blocks: the collecting system coupled to PV noted Block 1, the system for compacting the vegetation noted Block 2 and the drying of the collected vegetation, coupled also at PV noted Block 3.

The partially dried vegetation is used further into biomass power plant, noted Block 4. Separately were designed and executed the propulsion system of the pontoon, the command system from the lakeshore and the supply system from the PV panels. For all blocks is in progress to be realized a system of automation and inter-connection, permanently adapted to the meteorological conditions. 


\section{INTERNATIONAL SYMPOSIUM "THE ENVIRONMENT AND THE INDUSTRY", SIMI 2018, PROCEEDINGS BOOK}

\section{The Prototype functioning}

The model is placed on a mobile pontoon, which may advance by propulsion, depending on the amount of the collected vegetation, and commanded from the lakeshore. When it moves, Step 1, it collects the aquatic vegetation with a circular system with barrel equipped with a grater, rasps, and small holes. Rasps are necessary to keep the collected vegetation and the holes to release the water, back to the lake. The vegetation arrives directly, due to the barrel, into a system of compacting noted Step 2. When the tank is filled, the supply is interrupted, Step 3 and the pontoon stops Step 4. At a time interval, pre-selected in conformity with the vegetation density and atmospheric parameters, the compacting system starts, by the barrel and eliminates the water back into the lake, Step 5. After compacting, the vegetation is deposited into a fiberglass tank, Step 6, where is partially dried Step 7, due to the circulation of the warm water, assured by the solar panels. The fiberglass tanks are placed on the pontoon, under the PV panels. After being partially dried, the vegetation is evacuated-Step 8 and consumed in a biomass power plant, placed on the lakeshore. The entire installation intends to be autonomic after finishing the automation. After the evacuation of the dried vegetation is commanded the advance of the pontoon and the functioning cycle is re-loaded.

The main components

The photovoltaic system has been selected with a small weight, $18 \mathrm{~kg}$ for the panels with Power $1 \mathrm{KW}$ and $28 \mathrm{~kg}$ for the inverter. It is formed by an Off-Grid $1 \mathrm{~kW}-\mathrm{PV}$ with possible energy storage in network batteries, recommended in areas where there is no electricity. The photovoltaic panels are reliable modules with high yield and good efficiency.

The collecting system is designed for cutting and collect both the floating vegetation and the grassroots from a depth of 1.1-1.6 m, Figure 1-a. It has a knife-shaped "U" hydraulic adjustable in height, depending on the vegetation type, allowing the pontoon's circulation easily through the dense vegetation. After cutting the vegetation it assures the removing from the water, and bring it into the deck, with a steel site acting as the conveyer belt. The prototype moves, and via the drum with teeth collects the excess vegetation. It is conducted by a snail rotor system through a pipe partially open (for compacting and squeezing). The collected plants are deposited into a fiberglass tank on deck with a capacity of around $5 \mathrm{~m}^{3}$.
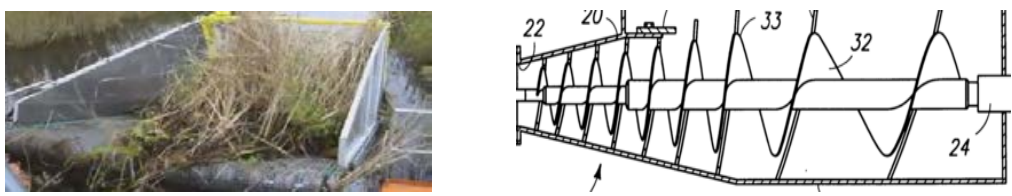

Figure 1. The collecting and the compacting systems for the vegetation

A silent engine environmentally friendly drives the hydraulic system of the collector. The propellers prove to be durable and anti-winding, ensuring a maximum 


\section{INTERNATIONAL SYMPOSIUM "THE ENVIRONMENT AND THE INDUSTRY", SIMI 2018, PROCEEDINGS BOOK}

maneuverability in both directions, back, and forth, even in shallow water with high vegetation.

The compacting system refers to a compression of the extracted vegetation, based on a screw system (augers), Figure 1-b. The screw is moving through a conic portion, assuring the compacting the vegetation and evacuation of the extracted water. The augers used to compact the vegetation will offer progressive compression into a semi-solid state. The materials have to be of high density as possible to ensure a maximum load concentration. A high volume and low density would be inefficient. The compacted vegetation, partially drained of water will be stored in a fiberglass tank as to be partially dried, placed on the pontoon, under the photovoltaic panels. The vegetation is only partially dried when is evacuated. The direct current generated by the solar modules feeds directly the heating element and convert into useful heat with an electrical efficiency of 98-99\%, without using an inverter. The heating system allows a permanent control of water temperature, in accordance of the atmospheric temperature, which saves costs and maintenance during functioning. If the vegetation remains wet after a cycle, or if a huge amount of vegetation is collected will be stored on a secondary drying rack, close to the biomass power plant, at the solar heat, Figure 2. It is placed in the sun, to hasten aeration and the final drying.

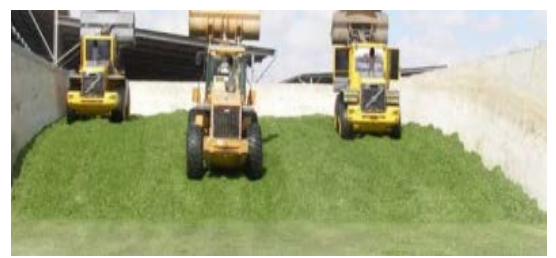

Figure 2. Storage system for vegetation

The pontoon stops when the fiberglass tank is full with the compacted vegetation. It is filled with vegetation until the level and weight sensors interrupt the movement and the alimentation of the pontoon. Here, through a pipeline system placed on the bottom, where circulates hot water, starts the partial drying of vegetation. When its weight decreased by $28 \%$ is considered a completed cycle, is downloaded the vegetation and a new cycle begin.

Figure 3 presents the basic structure of the biomass power plant based on the collected vegetation from the lake. 


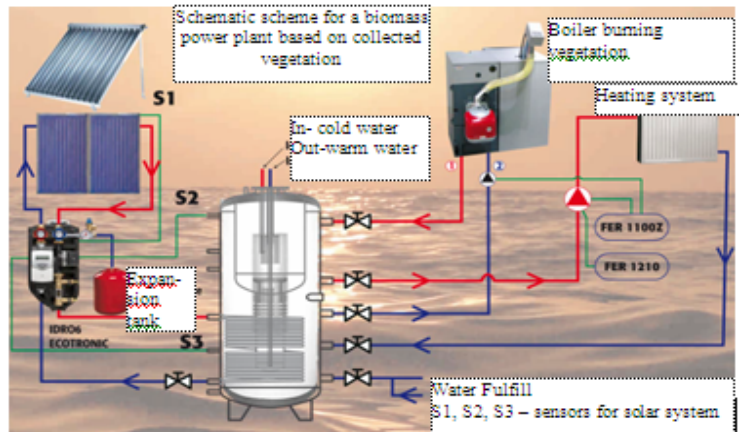

Figure 3. Schematic plan for the biomass power plant supplied with vegetation

The obtained warm water provides the heating for a building where is an aquatic plant nursery, with specific plants, and a bird's incubator from the local ecosystem for species still reduced as a number. There is also an annex to store the equipment during the winter.

\section{Conclusions}

The solution is ideal for cleaning the floating vegetation, and the developed aquatic vegetation from lakes Natural Reservations. The prototype may be extended into the future to collect some other solid floating material, like the plastic bottles, wood materials, etc. The model has a double effect; besides the collecting of the excess developed vegetation from the Lake Vaduri, this one is consumed as the main natural resource into a biomass power plant. In this sense, the solution contributes to the utilization of renewable technologies, the automation and embedded systems in industrial equipment. Under normal conditions of temperature and humidity, the amount of the harvested vegetation from a hydropower lake is between the values of

- 20-25 tons/ha/year dry, moisture content 0\%

- 33-42 tons/ha/year at 40\% humidity

The Vaduri Lake has a surface of 1500 ha, meaning

- 30.000 - 37.5000 tons/year dry, vegetation with moisture content $0 \%$

- 49.500 - 63.000 tons/year, vegetation with $40 \%$ humidity

The average price for vegetation is approx.

- 35-40 Euro/ton for humidity approx. 40\%

- 50-55 Euro/ton humidity 0\%

\section{References}

Cole, JJ, Peierls, BL, Caraco, NF \& Pace, ML 1993, 'Nitrogen loading of rivers as a human-driven process', M.J. McDonnell-S.T.A. Pickett, Springer-Verlag, New York, USA, pp. 141-157.

Duce, RA, LaRoche, J, Altieri, K, Arrigo, KR, Baker, AR, Capone, DG, Cornell, S, Dentener, F, Galloway, J, Ganeshram, RS, Geider, RJ, Jickells, T, Kuypers, 


\section{INTERNATIONAL SYMPOSIUM "THE ENVIRONMENT AND THE INDUSTRY", SIMI 2018, PROCEEDINGS BOOK}

MM, Langlois, R, Liss, PS, Liu, SM, Middelburg, JJ, Moore, CM, Nickovic, S, Oschlies, A, Pedersen, T, Prospero, J, Schlitzer, R, Seitzinger, S, Sorensen, LL, Uematsu, M, Ulloa, O, Voss, M, Ward, B, Zamora, L 2008, 'Impacts of Atmospheric Anthropogenic Nitrogen on the Open Ocean’, Science, vol. 320, pp. 893-89.

Lawton, LA \& Codd, GA 1991, 'Cyanobacterial (blue-green algae) toxins-their significance in UK and European waters', Journal of Soil and Water Conservation, vol. 40, pp. 87-97.

Martin, A \& Cooke, GD 1994, 'Health risks in eutrophic water supplies', Lake Line vol. 14, pp.24-26.

Rodhe, W 1979, 'Crystallization of eutrophication concepts in North Europe,' National Academy of Sciences, Washington D.C., Standard Book Number 309-01700-9, pp. 50-64.

Seteanu, I, Radulescu, V 1997, 'Infiltratia, difuzia si transferul biologic in ape de suprafata', Romanian House of the Romanian Academy, vol. 56, no. 5-6, pp. 285-295.

Shumway, SE 1990, 'A review of the effects of algal blooms on shellfish and aquaculture', Journal of the World Aquaculture Society, vol. 21, pp. 65-104.

Smith, VH, Tilman, GD \& Nekola, JC 1999, 'Eutrophication: impacts of excess nutrient inputs on freshwater, marine, and terrestrial ecosystems', Environmental Pollution, vol. 100, no. 1-3, pp. 179-196. 